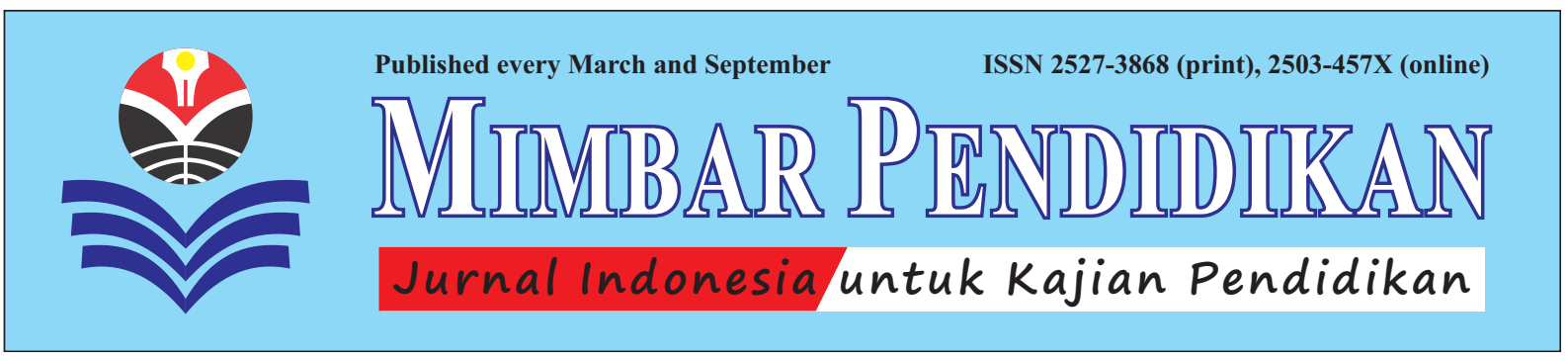

NANANG FATTAH \& BUDHI PAMUNGKAS GAUTAMA

\title{
Penerapan Biaya Pendidikan Berbasis Activity-Based Costing dalam Meningkatkan Mutu Pendidikan di Perguruan Tinggi: Studi Kasus di Universitas Pendidikan Indonesia
}

\begin{abstract}
ABSTRAKSI: Sebagai LPTK (Lembaga Pendidikan Tenaga Kependidikan), UPI (Universitas Pendidikan Indonesia) perlu melakukan suatu kajian untuk merancang sistem pengelolaan keuangan perguruan tinggi berbasis aktivitas dengan metode ABC (Activity-Based Costing), yang diharapkan akan dapat mengukur secara lebih rinci aktivitas-aktivitas utama dan pendukung dalam penyelenggaraan pendidikan. Hasil penelitian menunjukan bahwa seluruh Fakultas yang ada di lingkungan UPI menyatakan kesiapan untuk menerapkan sistem ABC. Berdasarkan FGD (Focus Group Discussion), terdapat beberapa kendala yang dihadapi untuk menerapkan sistem ABC di UPI di Bandung, Jawa Barat, Indonesia. Secara keseluruhan diperoleh hasil bahwa sistem ABC dapat diterapkan di UPI selama ada niat dan kerjasama yang baik dari Kementerian Pendidikan dan pimpinan Universitas.

KATA KUNCI: Biaya Pendidikan Berbasis Kegiatan; Uang Kuliah Tunggal; Mutu Pendidikan; Universitas Pendidikan Indonesia; Niat dan Kerjasama yang Baik.
\end{abstract}

ABSTRACT: "The Implementation of Activity-Based Costing to Improve the Quality of Education in Higher Education Institutions: A Case Study of Indonesia University of Education". As an institute of teacher training and education, UPI (Indonesia University of Education) needs to conduct a study on designing college financial management systems based on activity through the method of ABC (Activity-Based Costing), that is expected to be able to measure in more detail the main and supporting activities in the implementation of education. The results show that all Faculties at UPI declare their readiness to implement the ABC system. Based on the FGD (Focus Group Discussion), there are several problems in implementing ABC system at UPI in Bandung, West Java, Indonesia. Overall, the results show that ABC system can be applied in UPI as long as there is cooperation and good intention from the Ministry of Education and University leaders.

KEY WORD: Learning Activity-Based Costing; Single Tuition; Quality of Education; Indonesia University of Education; Cooperation and Good Intentions.

About the Authors: Prof. Dr. Nanang Fattah dan Budhi Pamungkas Gautama, M.Sc. adalah Dosen di Program Studi Manajemen FPEB UPI (Fakultas Pendidikan Ekonomi dan Bisnis, Universitas Pendidikan Indonesia), Jalan Dr. Setiabudhi No.229 Bandung 40154, Jawa Barat, Indonesia. Untuk kepentingan akademik, penulis bisa dihubungi dengan alamat emel: nanang1951@gmail.com dan bpg_im@yahoo.co.id

How to cite this article? Fattah, Nanang \& Budhi Pamungkas Gautama. (2017). "Penerapan Biaya Pendidikan Berbasis Activity-Based Costing dalam Meningkatkan Mutu Pendidikan di Perguruan Tinggi: Studi Kasus di Universitas Pendidikan Indonesia" in MIMBAR PENDIDIKAN: Jurnal Indonesia untuk Kajian Pendidikan, Vol.2(1) March, pp.19-32. Bandung, Indonesia: UPI [Indonesia University of Education] Press, ISSN 2527-3868 (print) and 2503-457X (online).

Chronicle of the article: Accepted (April 13, 2016); Revised (October 20, 2016); and Published (March 30, 2017). 


\section{PENDAHULUAN}

Di tengah iklim persaingan yang semakin tinggi diantara lembaga pendidikan, khususnya perguruan tinggi dalam hal kinerja, yang pada intinya berorientasi pada pencapaian WCU (World Class University), telah memiliki implikasi positif dan memberikan dorongan kuat bagi masingmasing institusi untuk semakin memperbaiki proses-proses internalnya dalam penyelengaraan pendidikan. Dalam tataran idealnya, pencapaian WCU memerlukan proses yang panjang dan berjenjang, mulai dari: Excellent Research-Based Teaching University, Research University, Regional Class University, sampai menuju World Class University (cf Osborne \& Gaebler, 1992; Susanto, 2014; Nasution, 2016; Nurmalasari, 2017; dan Syafri, 2017).

Seyogyanya hal ini disadari oleh segenap civitas akademika suatu perguruan tinggi agar memiliki orientasi dan komitmen yang sama dan jelas dalam hal pencapaian masing-masing tahapan tersebut. Suatu grand design mutlak diperlukan agar proses dimaksud dapat dipahami dan dilaksanakan secara optimal, mulai dari tingkatan strategis (pimpinan) sampai ke tingkatan operasional.

Fenomena ini pun disadari oleh UPI (Universitas Pendidikan Indonesia) di Bandung, sebagai salah satu dari 7 perguruan tinggi negeri yang berada dalam proses transformasi dari BHMN (Badan Hukum Milik Negara) menjadi perguruan tinggi yang diselenggarakan oleh pemerintah saat ini. Lebih jelasnya, sebagaimana didasarkan pada Peraturan Presiden Republik Indonesia Nomor 43 Tahun 2012 bahwa UPI berubah dari BHMN menjadi perguruan tinggi yang diselenggarakan oleh pemerintah, dengan menerapkan pola pengelolaan keuangan BLU atau Badan Layanan Umum. ${ }^{1}$

${ }^{1}$ Lihat, misalnya, berita "UPI Berubah dari BHMN Menjadi PT yang Diselenggarakan Pemerintah" dalam http://www.upi.edu/spot/id/81/upi-berubah-dari-bhmnmenjadi-pt-yang-diselenggarakan-pem [diakses di Bandung, Indonesia: 15 Januari 2017]
Berdasarkan pada konstatasi tersebut di atas, UPI sebagai lembaga pendidikan tinggi dituntut untuk lebih baik lagi dalam penyelenggaraannya, baik dalam hal academic excellence maupun manajemen perguruan tinggi, termasuk dalam hal pembiayaan; atau dengan kata lain yang berkaitan dengan penerapan good university governance (Bowen, 1981; Fattah, 2004; Julaeha, 2007; dan Lestari, 2013).

Berdasarkan hasil penelitian sebelumnya, yang mengkaji mengenai perancangan standar biaya pendidikan berbasis activitybased costing, dan dilaksanakan di UPI, menunjukan hasil bahwa perhitungan biaya yang dibutuhkan untuk membiayai kegiatan utama yang dijalankan di lingkungan UPI sangat bervariasi, berdasarkan masingmasing Fakultas yang ada di lingkungan UPI ( $c f$ Horngren et al., 2000; Fattah, 2004; Furqon, 2010; Duff \& Bull, 2011; dan Fontanella, Sukartini \& Chandra, 2015).

Komponen biaya yang dihitung dalam menentukan biaya kegiatan utama, yang dijalankan di lingkungan UPI dan berdasarkan metode ABC (Activity-Based Costing), yaitu: menghitung biaya dari berbagai aktivitas utama, yang terdiri dari biaya langsung dan biaya tidak langsung, yang dikeluarkan oleh para mahasiswa di setiap Fakultas, Jurusan, dan Program Studi yang ada di lingkungan UPI ( $c f$ Fattah, 2004; dan Fontanella, Sukartini \& Chandra, 2015).

Penerapan metode $\mathrm{ABC}$ yang digunakan untuk menentukan biaya dari kegiatan utama dan dijalankan di lingkungan UPI membutuhkan juga peran-serta dari pimpinan dan pengelola Universitas, baik dari tingkat pusat sampai ke tingkat bawah di lingkungan Fakultas, Jurusan, dan Program Studi, yang ada di lingkungan UPI. Kesadaran untuk menerapkan metode $\mathrm{ABC}$ ini tidak akan berjalan dengan baik, jika tidak ditunjang dengan pengetahuan mengenai komponen biaya apa saja yang timbul dalam menjalankan kegiatan utama di lingkungan UPI. 
Setiap orang yang ada di tingkat pusat dan di tingkat bawah pada Fakultas, Jurusan, dan Program Studi di lingkungan UPI harus memahami apa dan bagaimana cara untuk menerapkan metode $\mathrm{ABC}$ tersebut dengan baik, sehingga dapat ditentukan besarnya biaya pendidikan yang harus ditanggung oleh mahasiswa di lingkungan UPI; dan juga memberikan gambaran biaya langsung dan tidak langsung yang harus dikeluarkan dari berbagai kegiatan utama untuk menentukan kebijakan biaya kuliah serta subsidi yang harus dikeluarkan oleh pihak UPI terhadap biaya yang dikeluarkan oleh mahasiswa.

Persoalannya, mengacu pada beberapa data hasil penelitian terdahulu, yang berkaitan dengan mutu atau kualitas pelayanan di UPI, dan juga data-data yang berkaitan dengan lamanya masa studi, atau dikenal pula dengan istilah AEE (Angka Efisiensi Edukasi), secara umum, penyelenggaraan pendidikan di UPI masih harus lebih dioptimalkan lagi ( $c f$ Fattah, 2004; Furqon, 2010; dan Fontanella, Sukartini \& Chandra, 2015). Data hasil penelitian juga menunjukan masih terdapat beberapa unsur, seperti bimbingan akademik, sumber daya pendukung, dan pelayanan adminsitrasi yang masih perlu ditingkatkan lagi, karena masih berada di bawah apa yang diharapkan oleh mahasiswa sebagai stakeholder utama UPI (Fattah, 2004; dan Furqon, 2010).

Demikian pula dengan lamanya masa studi yang berkaitan pula dengan AEE di UPI, secara umum, sebetulnya UPI masih berada pada rentang ideal, walaupun terdapat beberapa Fakultas yang AEEnya masih tergolong rendah. Bila dikaji lebih jauh, maka perhitungan AEE ini berimplikasi pada pembiayaan pendidikan di suatu lembaga pendidikan. Hasil penelitian C. Furqon (2010) menunjukan bahwa di UPI pun terjadi pemborosan akibat keterlambatan masa studi mahasiswa, yang berkaitan biaya kesempatan yang hilang atau opportunity cost (Furqon, 2010).
Sistem ABC, sebenarnya, merupakan suatu kalkulasi biaya setiap aktivitas dan mengalokasikan biaya ke objek biaya, seperti produk barang atau jasa berdasarkan aktivitas yang dibutuhkan untuk memproduksinya (Horngren, Datar \& Foster, 2005:170). Sistem ABC adalah konsep akuntansi yang mampu mengurangi kelemahan dari akuntansi biaya tradisional, karena sistem $\mathrm{ABC}$ tidak hanya memandang biaya sebagai sesuatu yang harus dialokasikan, tetapi juga harus memahami apa saja aktivitas-aktivitas yang menjadi penyebab dari timbulnya biaya. Sistem ABC akan menunjukan bagaimana sumber daya dikeluarkan dengan menelusuri aktivitas-aktivitas yang dilakukan dalam menghasilkan produk (Munawir, 2002; Rudiyanto, 2006; dan Schnackenberg \& Tomlinson, 2014).

Dari apa yang telah dikemukakan sebelumnya dapatlah dikatakan bahwa sebagai perguruan tinggi, UPI dituntut untuk memperbaiki berbagai proses internalnya, meningkatkan efisiensi, dan berbagai hal lainnya. Oleh karena itu, UPI perlu mengetahui dengan jelas berbagai aktivitas utama dan pendukung dalam penyelenggaraan pendidikannya. Satu hal yang tidak dapat dipungkiri adalah bahwa pengelolaan keuangan merupakan hal yang krusial dalam mewujudkan pelayanan pendidikan yang berkualitas. Adanya proses transparansi, penerapan akuntabilitas, dan good university governance sangat esensial dalam upaya pembenahan pengelolaan keuangan, yang menjadi urat nadi dalam manajemen pendidikan tinggi (Horngren et al., 2000; Fattah, 2004; dan Fontanella, Sukartini \& Chandra, 2015).

UPI perlu mengoptimalkan keadaan tersebut dengan melakukan suatu kajian atau penelitian dengan menerapkan sistem pengelolaan keuangan perguruan tinggi berbasis aktivitas, dengan metode $\mathrm{ABC}$ atau Activity-Based Costing (Mulyadi, 2003; Fattah, 2004; Stephanie, 2008; Kusmayadi, 2012; dan Schnackenberg \& Tomlinson, 
2014). Penggunaan metode ABC ini diharapkan dapat mengukur secara lebih rinci aktivitas-aktivitas utama dan pendukung dalam penyelenggaraan pendidikan tinggi, biaya per aktivitas, faktor-faktor pendorong biaya, dan rata-rata biaya pendidikan, sehingga diharapkan bisa membantu proses peningkatan mutu pendidikan dengan proporsi dan alokasi yang lebih sesuai bagi berbagai aktivitas dalam penyelenggaraan pendidikan di UPI.

Demikian pula dari kajian yang dilakukan, ianya diharapkan dapat diterapkan model awal perancangan standar biaya pendidikan berbasis $\mathrm{ABC}$ dalam meningkatkan mutu pendidikan di UPI ( $c f$ Fattah, 2004; Furqon, 2010; dan Fontanella, Sukartini \& Chandra, 2015).

Tujuan Kajian. Secara umum, tujuan dari kajian ini adalah untuk mengetahui kesiapan dan keefektifan penerapan standar biaya pendidikan berbasis ABC (ActivityBased Costing) dalam meningkatkan mutu pendidikan di perguruan tinggi. Sedangkan secara khusus, penelitian ini bertujuan untuk: (1) Mendapatkan gambaran pengetahuan aktivitas utama dan pendukung dalam penyelengaraan pendidikan di perguruan tinggi; (2) Mendapatkan gambaran kesiapan penerapan standar biaya dari aktivitas utama dan pendukung dalam penyelengaraan pendidikan di perguruan tinggi; (3) Mendapatkan gambaran pengetahuan dan kefektifan standar biaya pendidikan dalam penyelengaraan pendidikan di perguruan tinggi; serta (4) Mendapatkan gambaran penerapan dan pengetahuan tentang faktor pendukung standar biaya pendidikan berbasis ABC dalam meningkatkan mutu pendidikan di UPI atau Universitas Pendidikan Indonesia.

\section{Good University Governance. Definisi} sederhana tentang good university governance dapat diartikan sebagai tatakelola yang baik, yang diterapkan pada tingkat universitas (Muhi, 2011). Pengertian sebenarnya dari good university governance adalah pengembangan dari good corporate governance, sehingga good corporate governance, yang diartikan menurut Bank Dunia, adalah aturan, standar, dan organisasi di bidang ekonomi yang mengatur perilaku pemilik perusahaan, direktur, dan manajer; serta perincian dan penjabaran tugas, wewenang, dan pertanggungjawabannya kepada investor atau pemegang saham dan kreditur (dalam Widodo, 2001; dan Muhi, 2011).

Akhmad Syakhroza (2003) mendefinisikan GCG (Good Corporate Governance) sebagai suatu mekanisme tata-kelola organisasi secara baik dalam melakukan pengelolaan sumber daya organisasi secara efisien, efektif, ekonomis, dan produktif dengan prinsip-prinsip terbuka, akuntabilitas, pertanggungjawaban, independen, dan adil dalam rangka mencapai tujuan organisasi (Syakhroza, 2003).

Biaya. Biaya merupakan kas atau nilai ekuivalen kas yang dikeluarkan oleh perusahaan untuk mendapatkan barang atau jasa, yang diharapkan berguna untuk memberikan suatu manfaat, yaitu peningkatan laba (Sudayat, 2009). Menurut Mulyadi (2006), tujuan pengorbanan sumberdaya adalah untuk menyediakan produk atau jasa guna memenuhi kebutuhan tertentu dari pelanggan (Mulyadi, 2006).

Untuk mewujudkan tujuan penyediaan produk atau jasa tersebut diperlukan aktivitas; dan aktivitas ini mengkonsumsi sumber daya. Dengan demikian, aktivitas merupakan penyebab langsung terjadinya suatu biaya. Penyediaan produk atau jasa merupakan penyebab suatu aktivitas dilaksanakan. Produk atau jasa, dengan demikian, merupakan sesuatu yang diperlukan untuk memenuhi kebutuhan tertentu pelanggan (Schedler, 1998; Fattah, 2004; dan Fontanella, Sukartini \& Chandra, 2015).

Activity-Based Costing. ABC (ActivityBased Costing) merupakan metode yang menerapkan konsep-konsep akuntansi aktivitas untuk menghasilkan perhitungan harga pokok produk yang lebih akurat 
(Lawrentis \& Simbolon, 2014; dan

Adinagoro, Suhadak \& Azizah, 2015).

Namun dari perspektif manajerial, sistem

ABC tidak hanya menawarkan lebih dari sekedar informasi biaya produk yang akurat, akan tetapi juga menyediakan informasi tentang biaya dan kinerja dari aktivitas dan sumber daya; serta dapat menelusuri biayabiaya secara akurat ke objek biaya selain produk, misalnya pelanggan dan saluran distribusi ( $c f$ Reich \& Abraham, 2006; Azizi, 2010; dan Lima, 2012).

Konsep ABC ini timbul karena sistem akumulasi biaya tradisional (traditional costing), yang biasa dipakai, tidak dapat mencerminkan secara benar besarnya pemakaian biaya produksi dan biaya sumber daya fisik. Fokus utama ABC adalah kegiatan atau aktivitas. Mengidentifikasi biaya kegiatan dan kemudian ke produk merupakan langkah dalam menyusun sistem ABC. Sistem ABC, dengan demikian, mengakui hubungan sebab-akibat atau hubungan langsung antara biaya sumber daya, penggerak biaya, kegiatan, dan objek biaya dalam membebankan biaya pada kegiatan dan kemudian pada objek biaya (Mulyadi, 2003; Stephanie, 2008; Kusmayadi, 2012; dan Schnackenberg \& Tomlinson, 2014).

Ada dua keyakinan yang melandasi sistem ABC, yaitu: (1) Biaya ada penyebabnya dan penyebab biaya adalah aktivitas; serta (2) Penyebab terjadinya biaya, yaitu aktivitas, dapat dikelola (Lawrentis \& Simbolon, 2014; dan Adinagoro, Suhadak \& Azizah, 2015).

Dalam penerapan di lembaga pendidikan tinggi, yang merupakan sebuah organisasi yang masuk kepada kategori non-profit atau nirlaba, sistem ABC menghitung pengeluaran keuangan berdasarkan kegiatan dan alokasi waktu untuk mengerjakan kegiatan tersebut. Langkah awal dalam sistem ABC ini adalah dengan mengidentifikasikan kegiatan yang disesuaikan dengan misi, tujuan, target, dan lingkup dari perguruan tinggi; serta tipe manajemen yang diharapkan bisa mengelola kegiatan tersebut (Schedler, 1998; Lawrentis
\& Simbolon, 2014; dan Adinagoro, Suhadak \& Azizah, 2015).

Setelah teridentifikasi kegiatan yang sesuai, pengalokasian biaya untuk kegiatan dilakukan dengan pendefinisian dari kegiatan tersebut. Dalam perguruan tinggi konvensional, kegiatan perguruan tinggi didefinisikan sebagai kegiatan pengajaran, kegiatan penelitian, dan kegiatan pengabdian kepada masyarakat (Fattah, 2004; dan Fontanella, Sukartini \& Chandra, 2015). Umumnya, di setiap bidang kegiatan tersebut digerakkan oleh administrasi, sehingga pembiayaan untuk kegiatan administrasi patut juga diperhitungkan tersendiri, sebagai bagian dari kegiatan di sebuah lembaga, sehingga tidak hanya mengalokasikan untuk 3 kegiatan (pengajaran, penelitian, dan pengabdian kepada masyarakat), akan tetapi harus juga mengalokasikan untuk kegiatan administrasi ( $c f$ Cox, Downey \& Smith, 1999; Fattah, 2004; dan Fontanella, Sukartini \& Chandra, 2015).

Setelah terdapat penetapan akan pendefinisian kegiatan, alokasi waktu untuk masing-masing Departemen (Fakultas, Jurusan, atau Program Studi) harus bisa disesuaikan dengan karakteristik dari setiap individu yang terlibat. Pendefinisian kegiatan dan alokasi waktu ini kemudian dianalisa pembiayaannya dan juga mengakumulasi sumber-sumber daya yang dapat menjadi cost driver (penggerak biaya) untuk kegiatan tersebut (Azizi, 2010).

Dalam konteks perguruan tinggi, cost driver adalah jumlah mahasiswa yang terlibat dalam kegiatan tersebut. Dalam menghitung penentuan cost driver adalah dengan melakukan pengidentifikasian aktivitas pada berbagai tingkat (Fattah, 2004; Furqon, 2010; Raiborn \& Kinney, 2011; dan Fontanella, Sukartini \& Chandra, 2015).

\section{METODE}

Pengolahan dan Analisis Data. Penelitian ini bersifat deskriptif dan verifikatif (Sumadi, 2005; dan Arikunto, 2008). Melalui jenis 
Tabel 1:

Hasil Uji Reliabilitas

\begin{tabular}{rccc}
\hline Variabel & $\mathbf{r}_{\text {hitung }}$ & $\mathbf{r}_{\text {tabel }}$ & Keterangan \\
\hline Activity-Based Costing & 0.756 & 0.576 & Reliabel \\
\hline
\end{tabular}

penelitian deskriptif, maka dapat diperoleh deskripsi mengenai bagaimana keefektifan penerapan model ABC (Activity-Based Costing) yang dilakukan di Fakultas; dan apa hambatan yang timbul dari masing-masing aktivitas utama di Fakultas, baik yang bersifat biaya langsung maupun biaya tidak langsung berdasarkan metode ABC (Kartadinata, 2000; Francesca, 2004; Made, 2006; Sarwono, 2008; dan Harrison, Jr. et al., 2011).

Berdasarkan jenis penelitian di atas, yaitu deskriptif yang dilaksanakan melalui pengumpulan data di lapangan, maka metode penelitian yang digunakan adalah deskriptif survey dan explanatori survey (Sumadi, 2005). Penelitian ini dilakukan dalam jangka waktu kurang dari satu tahun. Oleh karena itu, metode pengembangan yang digunakan adalah cross-sectional yang bersifat tunggal, yaitu salah satu rancangan riset yang terdiri dari pengumpulan informasi mengenai sampel tertentu dari elemen populasi hanya satu kali (Sumadi, 2005; dan Arikunto, 2008).

Teknik pengambilan sampel dalam penelitian ini adalah menggunakan criteria purposive sampling, yaitu memilih sampel secara tidak acak, dimana didasarkan pada pertimbangan tertentu yang dipandang dapat memberikan data secara maksimal (Arikunto, 2008). Sampel dalam penelitian ini adalah para pimpinan setiap Fakultas (Dekan dan Pembantu Dekan II) yang ada di lingkungan UPI (Universitas Pendidikan Indonesia) di Bandung, Jawa Barat, Indonesia.

Pertimbangan dalam pemilihan sampel tersebut karena Dekan dan PD II merupakan pimpinan UPI di tingkat Fakultas, yang memiliki wewenang sebagai penentu kebijakan dan memiliki akses mengenai anggaran kegiatan perkuliahan.

Pengujian Validitas. Pengujian validitas instrumen dalam penelitian ini dilakukan terhadap 12 responden, dengan tingkat signifikansi 5\% dan derajat kebebasan $\mathrm{df}=$ $\mathrm{n}-2$, yaitu $12-2=10$, sehingga diperoleh nilai $r_{\text {tabel }}$ sebesar 0.576. Maka, setiap item pertanyaan dalam instrument ini dapat dikatakan valid, karena $r_{\text {hitung }}$ pada setiap item menunjukan nilai yang lebih besar daripada $r_{\text {tabel }}\left(r_{\text {hitung }}>r_{\text {tabel }}\right)$. Hal ini berarti bahwa pertanyaan-pertanyaan dalam kuesioner dapat dijadikan alat ukur apa yang hendak diukur (Sumadi, 2005; dan Arikunto, 2008).

Mengenai pengujian reliabilitas dalam penelitian ini dapat dilihat dalam tabel 1 . Pengujian reliabilitas juga berdasarkan hasil pengolahan data dengan menggunakan SPSS (Statistical Package for Social Sciences) 21.0 for Windows 2014.

Berdasarkan tabel 1 diperoleh hasil uji reliabilitas variabel X menunjukan bahwa variabel tersebut dinyatakan reliable, karena nilai $r_{\text {hitung }}>r_{\text {tabel. }}$

\section{HASIL DAN PEMBAHASAN \\ Pertama, Gambaran Umum Biaya} Langsung pada Aktivitas Utama. Dari hasil penelitian berkaitan dengan penerapan standar biaya berbasis aktivitas dengan metode ABC (Activity-Based Costing), dengan menggunakan instrumen kuesioner/ angket yang telah dibuat, menunjukan bahwa para responden sebagian besar telah mengetahui semua komponen biaya yang termasuk dalam kategori biaya langsung, yang timbul dalam kegiatan/aktivitas utama perkuliahan. Responden juga mengetahui standar biaya-biaya pada biaya langsung, meski sebagian kecil responden mengaku masih kebingungan dalam membedakan mana yang termasuk pada komponen biaya langsung pada aktivitas utama perkuliahan. 
Untuk cara kalkulasi atau perhitungan biaya menggunakan metode $\mathrm{ABC}$, sebagian besar responden menyatakan bahwa mereka telah mengetahui cara kalkulasi tersebut. Namun, dalam proses penentuan biaya kuliah, sebagian besar responden menyatakan bahwa responden belum sepenuhnya menentukan besaran biaya berdasarkan kelompok biaya langsung.

Responden juga mengetahui dengan baik tentang besarnya biaya rata-rata pendidikan untuk kegiatan perkuliahan; mengetahui adanya biaya kesempatan yang hilang untuk setiap keterlambatan masa studi mahasiswa; serta mengetahui seluruh pembiayaan dan akumulasi sumber daya yang menjadi penggerak biaya dalam aktivitas utama kegiatan perkuliahan.

\section{Kedua, Gambaran Umum Biaya} Langsung pada Aktivitas Pendukung.

Dari hasil penelitian berkaitan dengan penerapan standar biaya berbasis aktivitas dengan metode ABC (Activity-Based Costing), dengan menggunakan instrumen kuesioner/angket yang telah dibuat, menunjukan bahwa para responden sebagian besar telah mengetahui semua komponen biaya yang termasuk dalam kategori biaya langsung, yang timbul dalam kegiatan/ aktivitas pendukung perkuliahan. Namun, sebagian besar dari responden menyatakan kurang mengetahui semua komponen biaya keseluruhan yang timbul dalam aktivitas pendukung yang terjadi. Mengenai standar biaya langsung, sebagian besar responden menyatakan bahwa mengetahui standar biaya-biaya langsung untuk aktivitas pendukung.

Mengenai cara kalkulasi biaya dengan metode $\mathrm{ABC}$, kegunaan dan manfaat penggunaan metode ini serta seluruh pembiayaan, dan akumulasi sumber daya penggerak biaya dalam aktivitas pendukung, sebagian besar responden menyatakan bahwa mereka mengetahui akan hal-hal tersebut.

Ketiga, Gambaran Umum Biaya Tidak Langsung pada Aktivitas Utama. Dari hasil penelitian berkaitan dengan penerapan standar biaya berbasis aktivitas dengan metode ABC (Activity-Based Costing), dengan menggunakan instrumen kuesioner/ angket yang telah dibuat, menunjukan bahwa para responden sebagian besar telah mengetahui semua komponen biaya yang termasuk dalam kategori biaya tidak langsung, yang timbul dalam kegiatan/ aktivitas utama perkuliahan.

Responden juga mengetahui standar biaya-biaya pada biaya tidak langsung, meski sebagian kecil responden mengaku masih kebingungan dalam membedakan mana yang termasuk pada komponen biaya tidak langsung pada aktivitas utama perkuliahan. Penerapan biaya-biaya dalam kegiatan utama perkuliahan, yang selama ini dilakukan di lingkungan UPI (Universitas Pendidikan Indonesia), masih dirasa kurang efektif dan efisien oleh sebagian besar responden.

Keempat, Gambaran Umum Biaya

\section{Tidak Langsung pada Aktivitas}

Pendukung. Dari hasil penelitian berkaitan dengan penerapan standar biaya berbasis aktivitas dengan metode ABC (ActivityBased Costing), dengan menggunakan instrumen kuesioner/angket yang telah dibuat, menunjukan bahwa para responden sebagian besar telah mengetahui semua komponen biaya yang termasuk dalam kategori biaya tidak langsung, yang timbul dalam kegiatan/aktivitas pendukung perkuliahan. Mengenai standar biaya tidak langsung, sebagian besar responden menyatakan bahwa tidak mengetahui standar untuk biaya-biaya tidak langsung dalam aktivitas pendukung perkuliahan.

Penerapan biaya-biaya dalam kegiatan pendukung perkuliahan yang selama ini dilakukan di lingkungan UPI (Universitas Pendidikan Indonesia) di Bandung, Jawa Barat, Indonesia masih dirasa kurang efektif dan efisien oleh para responden.

\section{Kelima, Gambaran Umum Faktor} Pendukung pada Aktivitas Utama. Dengan adanya penggunaan metode ABC (Activity- 
Based Costing) didalam pengelolaan dan penetapan standar biaya pendidikan berbasis aktivitas, responden menyatakan beberapa kelebihan yang didapat dengan menggunakan metode ini, seperti penerapan dan kalkulasi biaya pendidikan akan menjadi lebih efektif dan efisien. Responden juga dapat mengidentifikasi berbagai aktivitas dan mengukur besaran aktivitas dalam penentuan standar biaya pendidikan.

Responden kemudian menyatakan bahwa dengan penggunaan metode $\mathrm{ABC}$ akan terjadi transparansi biaya yang meningkat. Dengan metode ABC ini membuat para responden dapat mengidentifikasi dan mengukur variable cost dan fixed cost dalam kegiatan/aktivitas utama perkuliahan.

Keenam, Gambaran Umum Faktor Pendukung pada Aktivitas Pendukung. Dengan adanya penggunaan metode ABC (Activity-Based Costing) didalam pengelolaan dan penetapan standar biaya pendidikan berbasis aktivitas, responden menyatakan beberapa kelebihan yang didapat dengan menggunakan metode ini, seperti adanya perbaikan mutu sistem pengkajian biaya secara lebih efisien, lengkap, dan akurat. Selain itu, penggunaan metode ABC, menurut responden, akan berimbas pada pengurangan biaya, karena dapat mengelola aktivitas lebih baik (dapat pula memperbaiki aktivitas-aktivitas yang dirasa kurang bernilai tambah atau efisien).

Penggunaan metode $\mathrm{ABC}$ ini, menurut responden, dapat pula menghasilkan perkiraan standar biaya perkuliahan secara tepat, namun tetap sesuai dengan kebijakan dan peraturan yang berlaku. Metode $\mathrm{ABC}$ membuat para responden dapat mengidentifikasi dan mengukur variable cost dan fixed cost dalam kegiatan/aktivitas pendukung perkuliahan.

Sebagian besar responden menyatakan bahwa mereka dapat menentukan biaya joint cost yang timbul dari kegiatan manajemen di Fakultas masing-masing, yang digunakan untuk mendukung kegiatan perkuliahan.
Untuk biaya operasi non-personalia, yang timbul di setiap Fakultas di lingkungan UPI (Universitas Pendidikan Indonesia) sendiri, sebagian besar responden menyatakan bahwa terdapat perhitungan akan alokasi biaya alat tulis perkuliahan, biaya alat dan bahan habis pakai, biaya pemeliharaan dan perbaikan ringan, alokasi daya dan jasa, biaya transportasi/perjalanan dinas, serta alokasi biaya konsumsi dan pelaporan; sedangkan untuk perhitungan alokasi biaya asuransi hanya sebagian kecil saja responden yang memperhitungkan alokasi untuk biaya tersebut.

\section{Ketujuh, Gambaran Umum Faktor} Penghambat pada Aktivitas Utama. Penerapan metode ABC (Activity-Based Costing) didalam pelaksanaannya di lapangan pada aktivitas utama perkuliahan, menurut sebagian besar responden, penggunaan metode ini masih terhalang oleh beberapa faktor penghambat, seperti kesulitan menjalankan metode karena kurangnya pemahaman akan metode $\mathrm{ABC}$, belum terintegrasinya sistem akuntansi dan keuangan yang terkomputerisasi, serta berkaitan juga dengan biaya memiliki penggerak.

Kedelapan, Gambaran Umum Faktor Penghambat pada Aktivitas Pendukung. Penerapan metode ABC (Activity-Based Costing) didalam pelaksanaannya di lapangan pada aktivitas pendukung perkuliahan, menurut sebagian besar responden, penggunaan metode ini masih terhalang oleh beberapa faktor penghambat, seperti biaya konsumsi dan sumber daya yang terkadang tidak semuanya tepat dilakukan, mekanisme kontrol yang terkadang sulit dilakukan mengingat belum adanya standar operasional; serta ketentuanketentuan penentu efisiensi biaya yang pasti. Lihat bagan 1 .

Dari hasil perhitungan tersebut, sebagaimana nampak dalam bagan 1 , maka diperoleh nilai variabel X (ActivityBased Costing) sebesar 1997, selanjutnya 
hasil kuesioner tersebut ditunjukkan pada daerah kontinum. Daerah kontinum Activity-Based Costing terletak pada daerah tinggi, yaitu antara interval $1936-2640$.

Maka, dalam hal ini, para pimpinan tingkat Fakultas di UPI (Universitas

Pendidikan Indonesia) di Bandung, Jawa Barat, Indonesia telah optimal dalam melakukan penerapan metode $\mathrm{ABC}$ (Activity-Based Costing) guna meningkatkan mutu pendidikan.

Kendala dan Upaya. Tanggapan responden mengenai kendala dan upaya dalam memenuhi kebutuhan bidang akademik, serta komponen biaya yang menjadi prioritas untuk meningkatkan mutu pendidikan di UPI (Universitas Pendidikan Indonesia). Sebagian besar responden menyatakan bahwa terdapat beberapa kendala yang dihadapi untuk memenuhi kebutuhan bidang akademik, yaitu, diantaranya, terkait dengan kekurangan SDM (Sumber Daya Manusia) yang relevan dengan kompetensi yang dibutuhkan; pengadaan untuk kegiatan akademik masih dari dua sumber, yakni Universitas dan Fakultas; peralatan multimedia terbatas (belum bisa memenuhi semua kegiatan akademik ketika kegiatan akademik yang bersamaan tidak bisa dihindari); keterbatasan dana; serta adanya kebutuhan pemenuhan sarana praktikum dan penelitian.

Sedangkan kendala lainnya meliputi: belum ada keseragaman harga atas barang dan aktivitas yang mendetail (belum ada kebijakan yang mengikat atas keseragaman tersebut); aktivitas yang direncanakan sering berubah dan perubahannya tidak cukup dilindungi atau di back up aturan hukum; cost component praktikum masih kecil untuk Program Studi keteknikan; serta rasio alat praktek dengan mahasiswa masih tinggi.

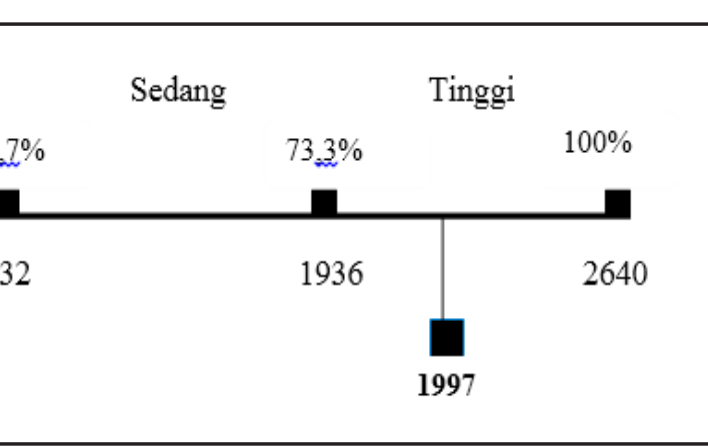

\section{Bagan 1: \\ Daerah Kontinum Variabel}

Adapun upaya yang telah dilakukan oleh sebagian besar responden untuk mengatasi kendala-kendala tersebut, yaitu, diantaranya, dengan mengkader SDM yang ada; koordinasi dengan Direktur Akademik di UPI agar beberapa pengadaan tidak tumpangtindih; kerjasama antar Program Studi sehingga sarana dari semua lembaga yang ada bisa dimanfaatkan; secara bertahap terus berupaya untuk bisa terpenuhinya sarana yang ada dengan memprogramkannya pada RKAT (Rencana Kegiatan dan Anggaran Tahunan), baik Fakultas maupun Program Studi; berusaha mendapatkan dana tambahan di luar RKAT; serta berusaha memperbesar anggaran dengan menentukan jumlah mahasiswa yang sesuai untuk rombongan belajar.

Sedangkan upaya lainnya yang telah dilakukan adalah dengan mengadakan dialog atau diskusi dengan para pengguna dana dan rekanan; menggunakan tenaga honorer, pensiun, dan lembaga lain; mengenalkan kebijakan yang bervariabel; mengandalkan adanya pendampingan dari petugas keuangan; mengusulkan adanya akuntan untuk setiap unit kerja keuangan; serta mengajukan pemenuhan sarana praktikum dan penelitian melalui APBNP (Anggaran Pendapatan dan Belanja Negara Perbaikan).

Selain hasil tersebut, terkait dengan peningkatan mutu pendidikan di UPI (Universitas Pendidikan Indonesia), sebagian besar responden menyatakan bahwa terdapat 
beberapa biaya komponen yang menjadi prioritas untuk menentukan peningkatan mutu pendidikan, khususnya di UPI, yaitu, diantaranya, gaji dosen dan karyawan; peningkatan kompetensi dosen dan staf; biaya pelatihan, seminar, dan konferensi; menyangkut pengadaan dan pemeliharaan; pemenuhan sarana multimedia untuk kelancaran pelaksanaan kuliah teori dan praktek, termasuk peralatan laboratorium; secara bertahap dengan berkoordinasi, baik secara internal Program Studi dan Fakultas maupun Universitas, penyelenggaraan praktikum yang berkualitas; serta penguasaan sarana pembelajaran di kelas.

Sedangkan biaya komponen lainnya yang menjadi prioritas untuk menentukan peningkatan mutu pendidikan, khususnya di UPI, yaitu, diantaranya, biaya publikasi; biaya penelitian dan pengabdian pada masyarakat; penciptaan kultur akademik berstandar internasional; kelengkapan sarana laboratorium; pembelajaran yang lebih kontekstual dan teknologis; praktikum pembelajaran di lapangan yang benar-benar terkendali; penelitian yang benar-benar bermanfaat untuk menyelesaikan masalah; tenaga ilmiah dan forum ilmiah yang dilakukan, baik lokal, nasional maupun internasional; serta pengabdian dosen atas keilmuan dan metodologi inovatif dalam memecahkan masalah di lapangan.

Hasil Focus Group Discussion. Terdapat beberapa kendala yang dihadapi dalam penerapan sistem ABC (Activity-Based Costing) di UPI (Universitas Pendidikan Indonesia) di Bandung, Jawa Barat, Indonesia. Kendala ini terlihat dari hasil survey perbandingan biaya perkuliahan antara LPTK (Lembaga Pendidikan Tenaga Kependidikan) dan non-LPTK. Kendala utamanya adalah terdapat perbedaan metode dan pendekatan dalam menentukan biaya perkuliahan, dimana perhitungan biaya perkuliahan masih berdasarkan budgeting based bukan activity based (Fattah, 2004). Mengenai budgeting-based costing, ianya merupakan pendekatan dan metode yang digunakan untuk menentukan biaya perkuliahan berdasarkan anggaran yang telah tersedia (Carter, 2009; dan Amrullah \& Kisworo, 2014). Sedangkan activitybased costing merupakan pendekatan dan metode yang digunakan untuk menentukan biaya perkuliahan berdasarkan segala aktivitas yang dijalankan (Schedler, 1998; Bustami \& Nurlela, 2009; dan Amrullah \& Kisworo, 2014). Sehingga, dengan adanya perbedaan tersebut, semakin menjelaskan bahwa penentuan biaya perkuliahan yang masih berdasarkan pendekatan dan metode budgeting-based costing hanya menentukan biaya perkuliahan berdasarkan anggaran yang ada, maka segala aktivitas perkuliahan yang dijalankan akan disesuaikan dengan anggaran yang ada.

Sedangkan jika penentukan biaya perkuliahan menggunakan metode dan pendekatan activity-based costing, maka penentuan biaya perkuliahan akan disesuaikan dengan segala aktivitas perkuliahan, sehingga nantinya akan berdampak pada terpenuhinya segala fasilitas yang dapat mendukung aktivitas perkuliahan. Dengan begitu, proses perkuliahan dapat berjalan dengan lancar, sehingga peningkatan mutu pendidikan pun akan lebih mudah tercapai (Fattah, 2004; dan Furqon, 2010).

Adanya perbedaan biaya perkuliahan antara LPTK dan non-LPTK ini tidak terlepas dari adanya kebijakan pemerintah yang ditujukan untuk seluruh LPTK yang ada, yaitu berkaitan dengan PTNBH (Perguruan Tinggi Negeri Berbadan Hukum), dimana kebijakan ini berkaitan dengan peraturan bahwa segala operasional yang terjadi didalam LPTK telah ditentukan dananya dari pemerintah pusat, sehingga segala aktivitas yang ada harus disesuaikan dengan anggaran yang telah tersedia (Fattah, 2004; dan Martusa \& Jennie, 2010).

Hal inilah yang menjadikan biaya perkuliahan di LPTK, termasuk di UPI, tidak sesuai dengan standar mutu biaya 
perkuliahan, sehingga biaya perkuliahan di LPTK tergolong lebih rendah jika dibandingkan dengan biaya perkuliahan di non-LPTK. Hal ini juga akan berdampak pada output yang dihasilkan. Output yang dihasilkan oleh LPTK dan non-LPTK terlihat jelas berbeda, terutama berkaitan dengan kompetensi yang dihasilkan (Noor, 2013).

Kompetensi LPTK tergolong jauh dibawah kompetensi non-LPTK. Hal ini tidak terlepas dari perbedaan standar biaya perkuliahan. Kompetensi non-LPTK yang tergolong tinggi dikarenakan adanya standar biaya perkuliahan yang tinggi pula, dimana perhitungan biaya perkuliahan disesuaikan dengan segala aktivitas yang dijalankan, sehingga fasilitas yang tersedia lebih lengkap dan dapat menunjang perkuliahan (Fattah, 2004). Sedangkan kompetensi LPTK berada dibawah non-LPTK. Hal ini jelas terjadi, karena standar biaya perkuliahan LPTK yang lebih rendah, sehingga fasilitas yang tersedia pun kurang dapat menunjang aktivitas perkuliahan, karena disesuaikan dengan anggaran yang ada.

Kompetensi yang berbeda antara LPTK dan non-LPTK membuat perbedaan tersebut semakin terlihat, karena kompetensi merupakan dasar dari terciptanya standar mutu untuk pendidikan (Suryadi \& Tilaar, 1993). Dapat dikatakan bahwa LPTK memiliki standar mutu pendidikan yang masih berada jauh dibawah non-LPTK. Selain itu, terdapat pula perbedaan berkaitan dengan kebijakan internal yang ada pada LPTK dan non-LPTK (Depdiknas RI, 2005). Adanya perbedaan kebijakan tersebut membuat management system yang ada di LPTK dan non-LPTK berbeda.

Sebaiknya, untuk menentukan biaya perkuliahan, terlebih dahulu memprediksi dan menentukan kebutuhan lulusan atau output. Hal ini dimaksudkan agar tujuan yang akan dicapai lebih jelas dan terarah. Dengan mengetahui terlebih dahulu mengenai kebutuhan dari segala aktivitas perkuliahan, maka perhitungan biaya perkuliahan dilakukan berdasarkan aktivitas yang ada, sehingga dengan adanya standar biaya berdasarkan aktivitas maka fasilitas yang tersedia dapat lebih menunjang untuk segala aktivitas yang dijalankan mahasiswa. Hal ini juga akan berdampak pada kompetensi yang dihasilkan menjadi lebih baik, sehingga terjadi peningkatan standar mutu pendidikan (Fattah, 2004; dan Furqon, 2010).

Untuk survey perbandingan biaya perkuliahan, seharusnya dibandingkan antara sesama PT (Perguruan Tinggi) LPTK, karena kebutuhan serta kebijakan yang dijalankan tidak jauh berbeda. Kebijakan standar yang diterapkan, lebih baik memperhitungkan pula standar biaya daerah, atau yang dikenal dengan IKK atau Indeks Kemahalan Konsumen (Syaiful, 2006; dan Muda, Helmi \& Kholis, 2014). Hal ini dikarenakan adanya perbedaan standar biaya setiap daerah, sehingga dapat mempengaruhi perhitungan biaya perkuliahan, karena disesuaikan juga dengan IKK yang ada di setiap daerah.

Selain itu, juga perlu adanya pengembangan SDM (Sumber Daya Manusia) agar tercipta SDM yang berkualitas, baik dari tingkat pengambil kebijakan maupun pelaksana (Yusraini, 2014). Serta juga perlu adanya pembinaan, baik pembinaan fasilitas, tenaga kependidikan, maupun pembinaan keahlian untuk menentukan biaya perkuliahan.

Hasil Kajian. Berdasarkan kajian teori, jurnal internasional, dan penelitian terdahulu mengenai model penelitian berdasarkan pada metode ABC (Activity-Based Costing), ianya berasumsi bahwa biaya merupakan kekuatan (power) untuk menghidupkan organisasi; biaya dimanfaatkan secara terfokus dan sesuai dengan bisnis inti (core business) dalam institusi pendidikan; biaya berkorelasi positif terhadap peningkatan kinerja organisasi, jika dimanfaatkan secara efektif dan efisien; serta terdapat perbedaan yang signifikan dalam pencapaian oraganisasi anatara yang menerapkan model ABC dengan pendekatan bottom up dengan 
pendekatan sentralisasi atau top down, yang selama ini digunakan oleh perguruan tinggi (Fattah, 2004; Schedler, 1998; Salvatore, 2005; Herbst, 2007; Shim \& Joel, 2009;

ADB, 2010 dan 2015; dan Furqon, 2010).

\section{KESIMPULAN}

Penggunaan metode ABC (Activity-Based Costing) dapat mengukur secara lebih rinci aktivitas-aktivitas utama dan pendukung dalam penyelenggaraan pendidikan tinggi. Hasil penelitian berdasarkan kuesioner menunjukan bahwa, secara akademik, seluruh Fakultas yang ada di lingkungan UPI (Universitas Pendidikan Indonesia) di Bandung, Jawa Barat, Indonesia menyatakan kesiapan untuk menerapkan sistem ABC guna tercapainya peningkatan standar mutu biaya perkuliahan.

Berdasarkan FGD (Focus Group Discussion) diperoleh hasil bahwa terdapat beberapa kendala yang dihadapi untuk menerapkan sistem ABC di UPI, sebagai universitas LPTK (Lembaga Pendidikan Tenaga Kependidikan). Secara keseluruhan diperoleh hasil bahwa sistem $\mathrm{ABC}$ dapat diterapkan di UPI, selama ada niat dan kerjasama yang baik dari berbagai pihak yang terkait, baik dari Kementerian Pendidikan maupun dari pimpinan Universitas.

Sebaiknya, dalam menerapkan biaya pendidikan, terlebih dahulu melakukan pendekatan, dimana melihat dari segi asumsi biaya (kebijakan dalam anggaran) dan segi management sytem (kebijakan dalam sistem manajemen), sehingga dapat tercapai standar mutu pendidikan yang lebih baik. Perlu adanya perhitungan mengenai standar biaya daerah, atau yang lebih dikenal dengan IKK (Indeks Kemahalan Konsumen), sehingga standar biaya perkuliahan dapat disesuaikan dengan kebutuhan setiap daerah.

Akhirnya, perlu juga ada kebijakan yang mendukung penerapan biaya pendidikan berbasis $\mathrm{ABC}$, dalam hal ini pengembangan SDM (Sumber Daya Manusia), sehingga terciptanya SDM yang berkualitas, baik dari tingkat pengambil kebijakan maupun pelaksana. $^{2}$

\section{Referensi}

ADB [Asian Development Bank]. (2010). The High Cost of Low Education Performance. Paris: OECD Publishing.

ADB [Asian Development Bank]. (2015). Education in Indonesia. Paris: OECD Publishing.

Adinagoro, Novan Setya, Suhadak \& Devi Farah Azizah. (2015). "Penerapan Analisis Activity Based Costing (ABC) Sistem untuk Penetapan Harga Pokok Produksi secara Akurat: Studi pada PT Cemara Mas Sidoarjo". Tersedia secara online di: http://download.portalgaruda.org/article. php?article [diakses di Bandung, Indonesia: 15 Januari 2017].

Amrullah, Muchamad \& Joko Kisworo. (2014). Analisis Perilaku Biaya dan Perhitungan Biaya Per Output Pendidikan dan Pelatihan dengan Pendekatan Activity Based Costing System pada PUSDIKLAT Anggaran dan Perbendaharaan Tahun Anggaran 2013. Jakarta: Badan Pendidikan dan Pelatihan Keuangan. Tersedia secara online juga di: file:///C:/Users/acer/Downloads/ muchamadamrullah dan jokokisworo.pdf [diakses di Bandung, Indonesia: 15 Januari 2017].

Arikunto, Suharsimi. (2008). Prosedur Penelitian. Jakarta: Rineka Cipta.

Azizi, Ismail Noor. (2010). Activity-Based Management in Higher Education: Can it Work? Kuala Lumpur: UM [University of Malaya] Press. Tersedia secara online juga di: www. emeraldinsight.com/1065-0741.htm [diakses di Bandung, Indonesia: 15 Desember 2016].

Berita "UPI Berubah dari BHMN Menjadi PT yang Diselenggarakan Pemerintah" dalam http:// www.upi.edu/spot/id/81/upi-berubah-dari-bhmnmenjadi-pt-yang-diselenggarakan-pem [diakses di Bandung, Indonesia: 15 Januari 2017].

Bowen, Howard R. (1981). The Cost of Higher Education. California, USA [United States

\footnotetext{
${ }^{2}$ Pernyataan: Dengan ini, kami menyatakan bahwa artikel ini, beserta seluruh isinya, benar-benar karya kami berdua dan tidak melakukan penjiplakan atau pengutipan dengan cara yang tidak sesuai dengan etika keilmuan yang berlaku dalam masyarakat keilmuan. Atas pernyataan ini, kami siap menanggung risiko ataupun sanksi yang dijatuhkan kepada kami, apabila di kemudian hari ditemukan adanya pelanggaran terhadap etika keilmuan dalam karya kami ini, atau klaim dari pihak lain terhadap keaslian karya kami ini.
} 
of America]: The Carnegie Foundation for Advancement of Teaching dan Jossey-Bass, Inc., second edition.

Bustami, Bastian \& Nurlela. (2009). Akuntansi Biaya melalui Pendekatan Manajerial. Jakarta: Mitra Wacana Media, edisi pertama.

Carter, William K. (2009). Akuntansi Biaya. Jakarta: Salemba Empat, edisi keempatbelas.

Cox, K.S., R.G. Downey \& L.G. Smith. (1999). "ABC's of Higher Education - Getting Back to the Basics: An Activity-Based Costing Approach to Planning and Financial Decision Making". Paper presented at the Association for Institutional Research 39th Annual Forum in Seattle, USA [United States of America].

Depdiknas RI [Departemen Pendidikan Nasional Republik Indonesia]. (2005). Rencana Strategis Pembangunan Pendidikan Nasional, 2005-2009. Jakarta: Sekretaris Jenderal Depdiknas RI.

Duff, R.R. \& M. Bull. (2011). Understanding Social Enterprise: Theory and Practice. London: Sage Publication.

Fattah, Nanang. (2004). Ekonomi dan Pembiayaan Pendidikan. Bandung: PT Rosdakarya.

Fontanella, Amy, Sukartini \& Novrina Chandra. (2015). "Implementasi Perhitungan Biaya Satuan (Unit Cost) Penyelenggaraan Pendidikan dengan Pendekatan Activity Based Costing (ABC): Peluang dan Tantangan (Studi Pada Politeknik Negeri Padang)". Tersedia secara online di: http:// fe.unp.ac.id/sites/default/files/unggahan [diakses di Bandung, Indonesia: 15 Januari 2017].

Francesca, Bartolaci. (2004). Activity-Based Costing in the Supply Chain Logistics Activities: Cost Analysis. Italy: Universita Degli Studi di Macerata.

Furqon, C. (2010). "Efektivitas Sistem Informasi Akademik di Perguruan Tinggi: Studi Deskriptif Analisis tentang Sistem Informasi Akademik di Universitas Pendidikan Indonesia". Disertasi Doktor Tidak Diterbitkan. Bandung: Program Studi Administrasi Pendidikan SPs UPI [Sekolah Pascasarjana, Universitas Pendidikan Indonesia].

Harrison, Jr., Walter T. et al. (2011). Akuntansi Keuangan, Jilid 1. Jakarta: Penerbit Erlangga, edisi kedelapan.

Herbst, Marcel. (2007). Financing Public Universities. The Netherlans: Springer.

Horngren, Charles T. et al. (2000). Akuntansi di Indonesia. Jakarta: Salemba Empat, Terjemahan.

Horngren, Charles T., Srikant M. Datar \& George Foster. (2005). Akuntansi Biaya: Penekanan Manjerial. Jakarta. Jakarta: PT Indeks Kelompok Gramedia, edisi kesebelas, alih bahasa oleh Desi Adhariani.

Julaeha, Ela. (2007). "Manajemen Pembiayaan dalam Perguruan Tinggi”. Tersedia secara online di: www.asm.ariyanti.ac.id [diakses di Bandung, Indonesia: 15 Januari 2017].

Kartadinata, Abas. (2000). Akuntansi dan Analisis Biaya. Jakarta: PT Rineka Cipta.

Kusmayadi. (2012). Activity-Based Costing in Global Era. Semarang: PNS [Politeknik Negeri Semarang] Press.

Lawrentis, Lisa \& Harry Andrian Simbolon. (2014). "Activity-Based Costing". Tersedia secara online di: https://akuntansiterapan.com/2014/02/17/ activity-based-costing/ [diakses di Bandung, Indonesia: 15 Januari 2017].

Lestari, Ambar Sri. (2013). “Analisis Penilaian Kinerja Lembaga Pendidikan Tinggi dengan Metode Balanced Scorecard: Penerapannya dalam Sistem Manajemen Strategis (Studi Kasus pada Universitas Brawijaya Malang)". Makalah disajikan dalam $2^{\text {nd }}$ International Seminar on Quality and Affordable Education (ISQAE). Tersedia juga secara online di: http://educ.utm.my/ wp-content/uploads/2013/11/61.pdf [diakses di Bandung, Indonesia: 15 Januari 2017].

Lima, Carlos Manuel Ferreira. (2012). “The Applicability of the Principles of Activity Based Costing System in a Higher Education Institution" in Faculdade de Economia do Porto Economics and Management Research Projects: An International Journal, ISSN 2184 $\square 0309$, published by Open Access International Journals Publisher. Tersedia secara online juga di: www. apps.fep.up.pt/oaij/index.php/EMRP/12 [diakses di Bandung, Indonesia: 15 Desember 2016].

Made, Wirartha. (2006). Metodologi Penelitian SosialEkonomi. Yogyakarta: CV Andi Offset.

Martusa, Riki \& Marsiana Jennie. (2010). "Penerapan Biaya Standar terhadap Pengendalian Biaya Produksi: Studi Kasus pada CV Sejahtera Bandung" dalam Jurnal Ilmiah Akuntansi, No.07, ISSN 2086-4159.

Muda, Iskandar, Syafrizal Helmi \& Azizul Kholis. (2014). "Kajian Pengaruh Indeks Kemahalan Konstruksi (IKK), Pertumbuhan Ekonomi, dan Alokasi Belanja Modal terhadap Indeks Pembangunan Manusia (IPM) di Sumatera Utara" dalam Jurnal Dinamika Akuntansi dan Bisnis, Vol.1, No.1 [Maret], hlm.12-29. Tersedia secara online juga di: http://download.portalgaruda.org/ article.php?article [diakses di Bandung, Indonesia: 15 Januari 2017].

Muhi, Ali Hanapiah. (2011). "Membangun Good Governance pada Perguruan Tinggi di Indonesia". Tersedia secara online di: http://alimuhi.staff. ipdn.ac.id/wp-content/uploads/2011/04/MEMB. GOOD .GOV .PADA .PT .pdf [diakses di Bandung, Indonesia: 15 Januari 2017].

Mulyadi. (2003). Activity Based Costing: Sistem 
Informasi Biaya untuk Pengurangan Biaya. Yogyakarta: Penerbit UPP AMP YKPN, edisi keenam.

Mulyadi. (2006). Akuntansi Biaya. Jakarta: Penerbit STIE YKPN.

Munawir, S. (2002). Analisis Laporan Keuangan. Yogyakarta: Penerbit YPKN, edisi kedua.

Nasution, Sakti. (2016). "Research, Mindset, and World Class University". Tersedia secara online di: http://belmawa.ristekdikti.go.id/2016/10/14/risetmindset-dan-world-class-university/ [diakses di Bandung, Indonesia: 15 Januari 2017].

Noor, Idris H.M. (2013). "Efektivitas Perubahan Lembaga Pendidikan Tenaga Kependidikan (LPTK)/Institut Keguruan dan Ilmu Pendidikan (IKIP) Menjadi Universitas" dalam Jurnal Pendidikan dan Kebudayaan, Vol.19, No.3 [September]. Tersedia secara online juga di: http:// jurnaldikbud.kemdikbud.go.id/index.php/jpnk/ article/viewFile/296/200 [diakses di Bandung, Indonesia: 15 Januari 2017].

Nurmalasari, Diah. (2017). "Makalah World Class University". Tersedia secara online di: http://www. academia.edu/11134037/makalah_world_class university [diakses di Bandung, Indonesia: 28 Februari 2017].

Osborne, David \& Ted Gaebler. (1992). Reinventing Government: How the Entrepreneurial Spirit is Transforming the Public Sector. Reading, MA: Addison-Wesley.

Raiborn, Cecily A. \& Michael R. Kinney. (2011). Akuntansi Biaya Dasar dan Perkembangan, Jilid Satu. Jakarta: Salemba Empat, edisi ketujuh.

Reich, F. \& A. Abraham. (2006). "Activity Based Costing and Activity Data Collection: A Case Study in the Higher Education Sector" in Proceeding of the $18^{\text {th }}$ Asian Pacific Conference on International Accounting Issues, in Maui, Hawaii, on 15-18 October.

Rudiyanto. (2006). Akuntansi Manajemen: Informasi untuk Pengambilan Keputusan Manajemen. Jakarta: Gramedia.

Salvatore, Barbaro. (2005). Equity and Efficiency Consideration of Public Higher Education. New York: Springer.

Sarwono, Jonathan. (2008). Riset Bisnis untuk Pengambilan Keputusan. Yogyakarta: CV Andi Offset.

Schedler, A. (1998). "Conceptualizing Accountability" in A. Schedler, L. Diamond \& M.G. Plattner [eds]. The Self-Restraining State, Power, and Accountability in New 328 Democracies. London: Lynne Rienner Publishers, pp.13-28.
Schnackenberg, A.K. \& E.C. Tomlinson. (2014). "Organizational Transparency: A New Perspective on Managing Trust in Organization Stakeholder Relationships" in Journal of Management, Vol.5, No.2.

Shim, K. Jae \& Siegel G. Joel. (2009). Budgeting: Basic and Beyond. New Jersey: John Wiley and Son, Inc.

Stephanie, Edwards. (2008). Activity Base Costing. United Kingdom: The Chartered Institute of Management Acoountants. Tersedia secara online di: www.CIMAglobal.comdi [diakses di Bandung, Indonesia: 16 April 2016].

Sudayat, Ridwan Iskandar. (2009). "Pengertian Biaya". Tersedia secara online di: https:// ridwaniskandar.files.wordpress.com/2009/05/31pengertian-biaya.pdf [diakses di Bandung, Indonesia: 16 April 2016].

Sumadi, Suryabrata. (2005). Metodologi Penelitian. Jakarta: PT Raja Grafindo Persada.

Suryadi, Ace \& H.A.R. Tilaar. (1993). Analisis Kebijakan Pendidikan: Suatu Pengantar. Bandung: PT Remaja Rosdakarya.

Susanto. (2014). "Strategi Menuju World Class University pada Universitas Semarang (Strategies to World Class University at Semarang University)" dalam Jurnal Transformatika, Vol.11, No.2 [Januari], hlm.87-95. Tersedia secara online juga di: file:///C:/Users/acer/Downloads/100268-1-PB.pdf [diakses di Bandung, Indonesia: 15 Januari 2017].

Syafri, Rini. (2017). "World Class University: Kemajuan atau Justru Kemunduran?". Tersedia secara online di: http://hizbut-tahrir. or.id/2017/02/15/world-class-university-kemajuanatau-justru-kemunduran/ [diakses di Bandung, Indonesia: 28 Februari 2017].

Syaiful. (2006). Pengertian dan Perlakuan Akuntansi Belanja Barang dan Belanja Modal dalam Kaidah Akuntansi Pemerintahan. Jakarta: Diklat Depdagri [Pendidikan dan Latihan, Departemen Dalam Negeri].

Syakhroza, Akhmad. (2003). "Theory of Good Corporate Governance" dalam Majalah Usahawan Indonesia, Vol.XXXII, No.08, hlm.19-25.

Widodo, J. (2001). Good Governance: Telaah dari Dimensi Akuntabilitas dan Kontrol Birokrasi pada Era Desentralisasi dan Otonomi Daerah. Surabaya: Insan Cendikia.

Yusraini. (2014). "Implementasi Manajemen Sumber Daya Manusia: Tenaga Pendidik dan Kependidikan untuk Meningkatkan Mutu Layanan Pendidikan" dalam Jurnal Al- 'Ulum, Vol.1. Tersedia secara online juga di: http://download.portalgaruda.org/ article.php?article [diakses di Bandung, Indonesia: 28 Februari 2017]. 